\title{
Relationship between gender and clinical characteristics, associated factors, and hypertension treatment in patients with resistant hypertension
}

\author{
Katarzyna M. Hanus ${ }^{1}$, Aleksander Prejbisz ${ }^{1}$, Jerzy Gąsowski ${ }^{2}$, Marek Klocek ${ }^{3}$, Roman Topór-Mądry ${ }^{4,5}$, \\ Wiktoria Leśniak ${ }^{6}$, Marek Kabat ${ }^{1}$, Danuta Czarnecka ${ }^{3}$, Kalina Kawecka-Jaszcz ${ }^{3}$, \\ Krzysztof Narkiewicz ${ }^{7}$, Andrzej Januszewicz ${ }^{1}$ \\ 'Department of Hypertension, Institute of Cardiology, Warsaw, Poland \\ 2Department of Internal Medicine and Gerontology, Jagiellonian University Medical College, Krakow, Poland \\ ${ }^{3} 1^{\text {st }}$ Department of Cardiology, Interventional Electrocardiology, and Hypertension, Jagiellonian University Medical College, Krakow, Poland \\ ${ }^{4}$ Faculty of Health Sciences, Jagiellonian University Medical College, Krakow, Poland \\ ${ }^{5}$ Faculty of Health Sciences, Wroclaw Medical University, Wroclaw, Poland \\ ${ }^{6} 2^{\text {nd }}$ Department of Internal Medicine, Jagiellonian University Medical College, Krakow, Poland \\ 'Department of Diabetology and Hypertension, Medical University of Gdansk, Gdansk, Poland
}

\begin{abstract}
Background and aim: Recent meta-analyses indicate that the pooled prevalence of resistant hypertension (RHT) barely differs between the sexes. However, differences between women and men with RHT in patient characteristics, associated factors, and hypertension (HT) management are still not well-described.

Methods: In the cross-sectional questionnaire-based observational study we included 7306 hypertensive females and 5069 hypertensive males, $\geq 18$ years old, and treated for at least 12 months with antihypertensive drugs. We defined HT control as blood pressure (BP) levels both $<140 \mathrm{~mm} \mathrm{Hg} /<90 \mathrm{~mm} \mathrm{Hg}$. Patients were divided into three groups: controlled $\mathrm{HT}$, uncontrolled HT (not fulfilling the criteria of RHT), and RHT (uncontrolled HT despite using three antihypertensive drugs including diuretic). Cardiovascular (CV) risk was evaluated according to $2013 \mathrm{ESH} / \mathrm{ESC}$ guidelines.

Results: There were no differences in the rates of controlled HT (47.6\% vs. $47.0 \%)$, uncontrolled HT (27.3\% vs. $28.8 \%)$, and RHT ( $25.1 \%$ vs. $24.2 \%)$ between women and men, respectively $(\mathrm{p}=0.17)$. Among patients with RHT, women were older than men and had lower diastolic BP and estimated glomerular filtration rate (eGFR) as well as higher pulse pressure (PP). Cerebrovascular diseases $(16.9 \%$ vs. $14.3 \% ; p=0.062)$, abdominal obesity, and metabolic syndrome (MS, $70.5 \%$ vs. $60.1 \% ; p<0.001$ ) were more frequent among women than men with RHT. Women with RHT had higher rate of high/very high added CV risk in comparison to men. In a multivariate model higher PP, presence of MS, CV disease, and eGFR $<60 \mathrm{~mL} / \mathrm{min} / 1.73 \mathrm{~m}{ }^{2}$ were related to the presence of RHT both in males and females. In women RHT was also related to abdominal obesity, cerebrovascular diseases, and diseases causing disability. In men, RHT was additionally related to diseases requiring treatment with non-steroidal anti-inflammatory drugs.

Conclusions: Although there were no differences in the rate of RHT between women and men, we identified gender-related differences in CV risk profiles in RHT patients and in factors related with the presence of RHT. When divided into age groups, RHT was less frequent in women aged less than 40 years and aged between 40 and 65 years, and among patients 65 years and older there was a tendency towards a higher rate of HT in women.
\end{abstract}

Key words: antihypertensive treatment, cardiovascular risk, resistant hypertension

Kardiol Pol 2017; 75, 5: 421-431

Address for correspondence:

Katarzyna M. Hanus, MD, Department of Hypertension, Institute of Cardiology, ul. Alpejska 42, 04-628 Warszawa, Poland, e-mail: k.hanus1991@gmail.com Received: 29.09.2016 Accepted: 05.01.2017 Available as AoP: 27.01.2017

Kardiologia Polska Copyright (C) Polskie Towarzystwo Kardiologiczne 2017 


\section{INTRODUCTION}

Hypertension (HT) is more common in women than in men in ageing populations. In Europe and the United States, one in three adults presents with arterial hypertension. Noteworthy are the differences between women and men in younger age groups (18 and 29 years), showing a prevalence of $1.3 \%$ in women and $8.5 \%$ in men and $7.3 \%$ in women vs. $15.8 \%$ in men in people at the age of $30-44$ years. No major sex differences in clinical manifestations of HT outside of pregnancy-related HT have been described [1-5].

According to current clinical practice guidelines, no differences between men and women have been documented regarding diagnostic approaches for HT. As far as the differences between genders in hypertensive patients are concerned, female sex stands among the factors associated with a higher prevalence of white coat $\mathrm{HT}$, whereas male sex is related to increased prevalence of masked HT [1-5].

Hypertensive women sustain higher left ventricular ejection fraction but they exhibit less regression under medical therapy and they have estimated three-fold higher risk for developing congestive heart failure (HF) or stroke compared with men. Women with HT develop more vascular and myocardial stiffness than men at old age, and more often have isolated systolic HT, reflecting aortic stiffness [1-5].

It has been shown that patients with resistant hypertension (RHT) are at disproportionately higher risk for target organ damage and cardiovascular (CV) events, compared with the general hypertensive population. The recognition and identification of individuals with RHT is of particular importance, given the fact that they may require further diagnostic evaluation for specific interventions. Recent meta-analyses indicate that the pooled prevalence of RHT barely differed between sex. However, differences between male and female RHT patients in their characteristics, associated factors, and HT management are not well-characterised [6].

The aim of the analysis of the Pol-Fokus study was to compare women and men with RHT and to analyse if in patients with RHT there are sex differences in associated factors and HT treatment methods.

\section{METHODS}

The methodology of the Pol-Fokus study has already been published [7]. In brief, Pol-Fokus was a large, observational, cross-sectional survey of hypertensive subjects managed by general practitioners (GPs), cardiologists, and hypertension specialists throughout the Polish territory. The study was approved by the Ethics Committee of Jagiellonian University in Krakow, Poland and all participants provided informed consent. Nine hundred and seventy-eight GPs and 286 specialists (cardiology and hypertensiology) from all provinces in Poland participated in the Pol-Fokus study [1, 7].

The methods of selection of this group have already been described in detail $[1,7,8]$.
The Pol-Fokus study included hypertensive patients meeting the following criteria: age 18 years or more, HT treated for at least one year, with at least one visit to the doctor (participating in the study) over the last year. They had to be free from any acute disease in the preceding four weeks and from known secondary causes of HT. After exclusion of data obtained from doctors who did not achieve the specific quota or who provided incomplete questionnaires, as well as patients who were included despite not meeting the inclusion criteria and patients with no data regarding antihypertensive treatment, we finally analysed data from 12,375 patients.

Patients underwent standard clinical evaluation. The known duration of the HT was recorded. Weight and height as well as waist circumference were measured. Body mass index (BMI) was calculated. Abdominal obesity was defined as a waist circumference $>102 \mathrm{~cm}$ in men and $>88 \mathrm{~cm}$ in women. Currently used antihypertensive medications were also documented. Plasma sodium, potassium, glucose, creatinine, total cholesterol, low-density lipoprotein (LDL) cholesterol, high-density lipoprotein (HDL) cholesterol, and triglycerides concentration were measured, history of coronary artery disease (CAD), previous myocardial infarction, HF, arrhythmias, cerebrovascular diseases (CVD, including previous transient ischaemic attack, or stroke), asthma or chronic obstructive pulmonary disease, depression or anxiety, diabetes, and other diseases were assessed. The estimated glomerular filtration rate (eGFR) was calculated according to the Modification of Diet in Renal Disease (MDRD) study formula. CV risk (stratification into two groups: low/moderate and high/very high added risk) and characteristics of metabolic syndrome (MS) were evaluated according to the 2013 European Society of Hypertension/European Society of Cardiology (ESH/ESC) guidelines [2].

Blood pressure (BP) was measured in patients in the sitting position after a 5 min rest. Based on upper arm circumference, an appropriately sized cuff was put $2 \mathrm{~cm}$ above the antecubital fossa. Three consecutive readings were performed. The average of these three readings was recorded. Each participating doctor was provided with a detailed instruction for BP measurement. Use of devices with proven accuracy was recommended.

We defined HT control as BP levels lower than $140 \mathrm{~mm} \mathrm{Hg}$ for systolic BP (SBP) and lower than $90 \mathrm{mmHg}$ for diastolic BP (DBP). Hypertension was defined as resistant when a therapeutic strategy including diuretic and two other antihypertensive drugs failed to lower SBP and DBP values to $<140 \mathrm{~mm} \mathrm{Hg}$ and $<90 \mathrm{~mm} \mathrm{Hg}$. For this analysis, we divided patients into three groups: with controlled HT, uncontrolled HT (not fulfilling the criteria of RHT), and RHT.

\section{Statistical analysis}

Data analysis was carried out using the statistical software PASW Statistics 18 (SPSS Inc., Chicago, Illinois, United States). 


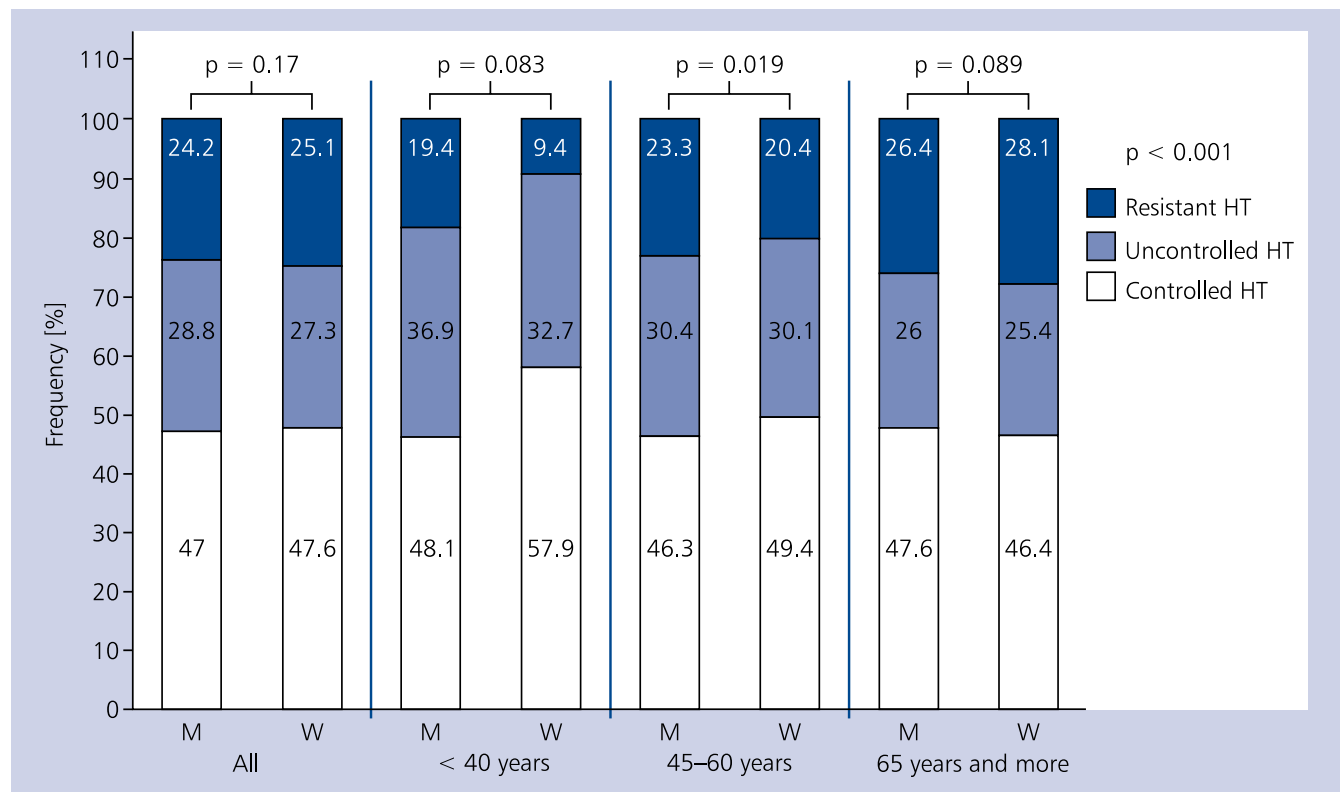

Figure 1. Prevalence of controlled, uncontrolled, and resistant hypertension (HT) in men and women according to the age groups; $\mathrm{M}$ - men; $\mathrm{W}$ - women

The results are presented as mean \pm one standard deviation or median and interquartile range. The values of variables were compared between groups: in the case of continuous and discrete variables by Student's t test, Mann-Whitney test, or univariate ANOVA analysis with Duncan post-hoc test, and in the case of categorical variables by $\chi^{2}$ test or Fisher exact test. Multivariate logistic regression models were performed to determine the combined effect of several variables on the prevalence of specific characteristics. For multivariate analysis, the variables with significant association were included. Multicollinearity was checked by variation inflation factor. $\mathrm{P}<0.05$ was considered statistically significant.

\section{RESULTS}

We included 7306 women (mean age $65.6 \pm 11.8$ years, range $18-98$ years) and 5069 men (mean age $61.7 \pm 12.6$ years, range 18-98 years). Among the women 3476 (47.6\%) had controlled HT, 1997 (27.3\%) - uncontrolled HT, and $1833(25.1 \%)$ - RHT; whereas among men it was $2381(47.0 \%), 1461(28.8 \%)$, and $1227(24.2 \%)$, respectively $(p=0.17$; Fig. 1$)$. The mean age of patients with RHT was significantly higher in women than in men (Table 1).

In patients with RHT, there were no differences between males and females in SBP levels. Women with RHT were characterised by lower DBP and higher pulse pressure (PP) than men.

Among patients with RHT women more often had MS and abdominal obesity than men. There was no difference in the frequency of diabetes between men and women (Table 2). Lower levels of eGFR were observed in women, and the prevalence of eGFR $<60 \mathrm{~mL} / \mathrm{min} / 1.73 \mathrm{~m}^{2}$ was significantly higher in women in comparison with men (Tables 1, 2). There were no differences between women and men in sodium, potassium, total cholesterol, LDL-cholesterol, HDL-cholesterol, triglycerides, and glucose levels (Table 1). Women with RHT had higher rate of high/very high added CV risk in comparison to men (Fig. 2).

There were no differences in the rates of $\mathrm{CV}$ diseases and CAD between men and women with RHT. The prevalence of $\mathrm{HF}$ was higher in men than in women. Other diseases including depression, diseases requiring the use of non-steroidal anti-inflammatory drugs, and diseases causing disability were more frequent in women with RHT than in men (Table 2).

There was no difference between women and men in the number of antihypertensive drugs. There were also no differences in the rate of use of particular antihypertensive drug classes between men and women with RHT, except for alpha-blockers, which were used more often by men (Table 3). We analysed the rate of use of the preferred three-drug combination (angiotensin converting enzyme inhibitor [ACEI] or angiotensin II receptor blocker [ARB] and calcium channel blocker [CCB] and thiazide/thiazide-type diuretic), and there was no difference between men and women in either the whole group of patients or in any particular clinical situation (Fig. 3).

To assess which factors are independently related to RHT in men and women, we performed a multivariate analysis including sex, age, PP, abdominal obesity, MS, diabetes, CAD, CVD, diseases requiring treatment with non-steroidal anti-inflammatory drugs, diseases causing disability, depression 


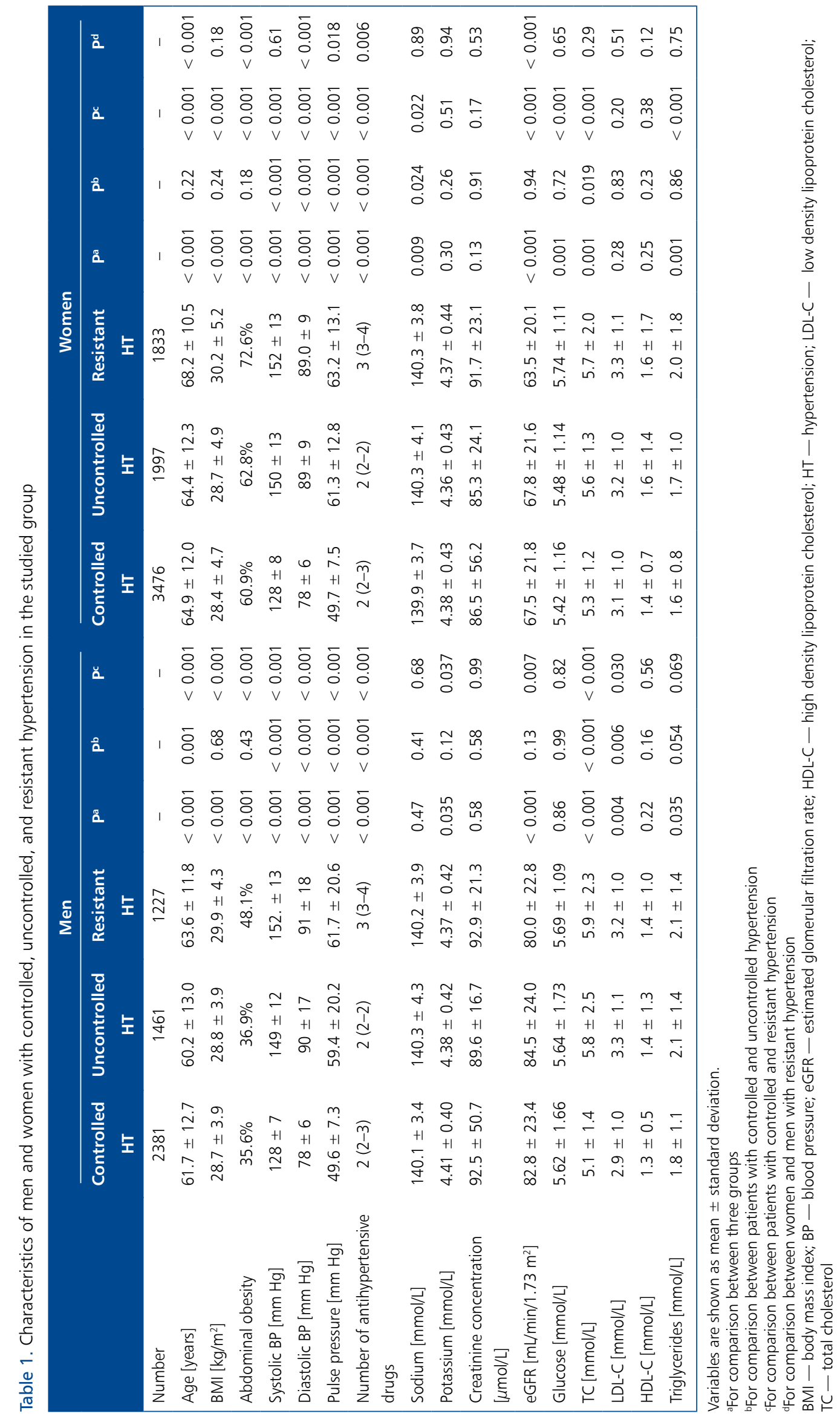




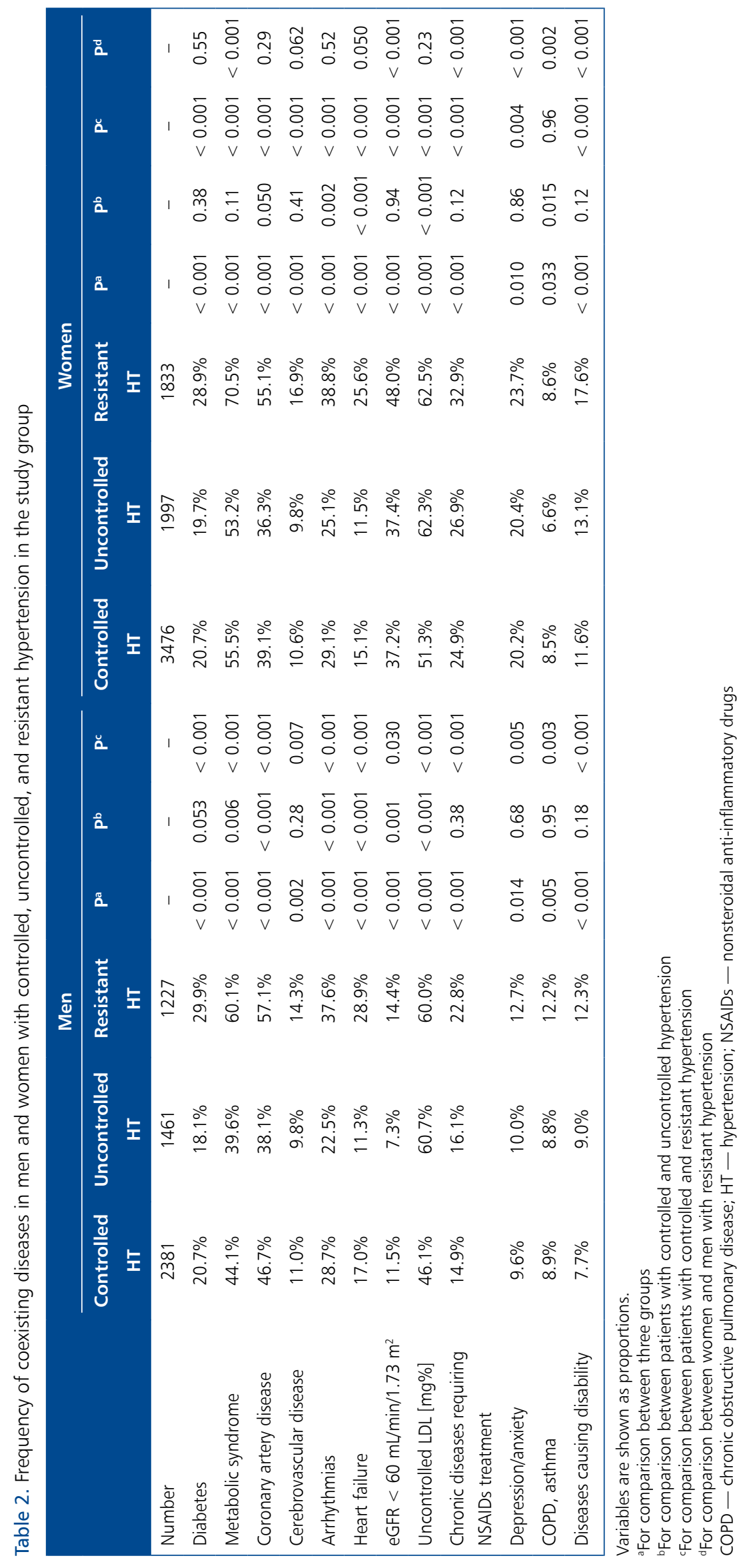




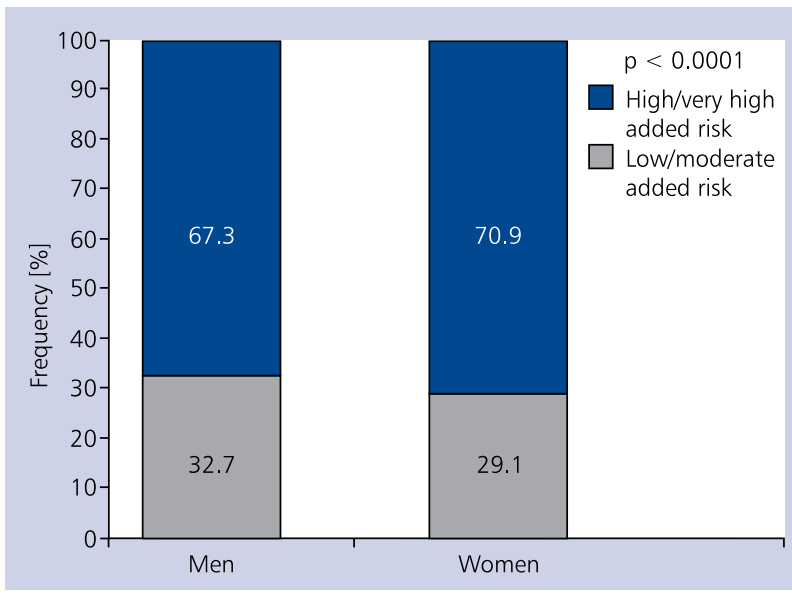

Figure 2. Comparison of cardiovascular risk stratification in participating women and men according to the 2013 European Society of Hypertension/European Society of Cardiology clinical practice guidelines

or anxiety, and eGFR of less than $60 \mathrm{~mL} / \mathrm{min} / 1.73 \mathrm{~m}^{2}$. Factors independently related to the RHT both in men and women were higher PP, MS, CAD, and an eGFR of less than $60 \mathrm{~mL} / \mathrm{min} / 1.73 \mathrm{~m}^{2}$. Additionally, in women the presence of RHT was independently associated with abdominal obesity, prior CVD, and diseases causing disability, whereas in men the presence of RHT was independently associated with the use of non-steroidal anti-inflammatory drugs (Table 4).

\section{DISCUSSION}

There is growing body of evidence in current literature about patients' characteristics, related risk factors, and therapy regarding RHT. Nevertheless, little is known about gender differences in patients with RHT.

In most studies male sex seems to be a risk factor of RHT [3, 9-11]. The Anglo Scandinavian Cardiac Outcome Trial (ASCOT) conducted on previously untreated patients revealed that baseline SBP and choice of subsequent antihypertensive therapy were the two most important determinants of RHT [3]. However, other factors including male sex and increased BMI were also significant determinants of RHT in this population.

The opposite point of view is presented in the study of Smith et al. [12], indicating that, among other factors, female sex, increasing age, and BMI were associated with RHT. It should be noted that results of Pol-Fokus do not provide strong evidence that female or male gender may be a significant risk factor of RHT.

In other studies, the prevalence of RHT between females and males varied depending on the analysed population. The study by Egan et al. [9] performed between 2007 and 2010 in 468,877 hypertensive patients showed that age, the percentage of men, $\mathrm{BMI}$, and the frequency of other factors were higher in those with apparent RHT as compared to other groups of hypertensive patients.
Achelrod et al. [13], in a systematic review and meta-analysis based on nine observational studies including the Northern American population, indicated that differences in RHT prevalence between sexes are negligible, whereas in a cross sectional study on 1217 Malaysian, Chinese, and Indian patients with hypertension, $8.8 \%$ of the participants had RHT and $64.4 \%$ of them were females [14].

However, it should be noted that other available studies support the concept that female sex is more frequent in RHT patients $[5,15,16]$.

Our study showed that the prevalence of RHT in patients with HT was $24.7 \%$, which is relatively high. There was no difference in the frequency of RHT between women and men (Fig. 1); however, the analysis of age subgroups revealed that RHT was less frequent in women at the age of $<40$ years and 40-65 years. Among patients 65 years old and above there was a tendency towards higher rate of HT in women (Fig. 1).

This observation may be because women in the Pol-Fokus study were generally older than men, which — based on the scientific data - confirms the relationship between higher age and more frequent prevalence of RHT $[9,14,17]$

Based on the NATPOL PLUS study conducted in 2002, the prevalence of HT in the general population also differs between age groups. The older the patient, the higher the observed frequency of HT. In 40-59-year-old people the prevalence of HT was 34\% (female [F]: $34 \%$, male [M]: $34 \%$ ), and in older than 59 years it was 57\% (F: 60\%, M: 54\%). Multivariate logistic regression revealed a significant impact of the older age, obesity, and educational level on the frequency of HT in the Polish population [4].

Contrary to the NATPOL PLUS study, our results indicate that significant differences in the prevalence of RHT between females and males occurred in patients at the age of 45-60 years.

The prevalence of vascular risk factors including obesity, hyperlipidaemia, diabetes, CAD, or CV disease is higher in subjects with RHT, as compared to patients with controlled HT $[7,8]$. However, in our study it was shown that there were no significant differences in the occurrence of risk factors between the genders except for MS and renal function decrease manifested by eGFR less than $60 \mathrm{~mL} / \mathrm{min} / 1.73 \mathrm{~m}^{2}$.

The observed lower eGFR in women with RHT may result from their higher age at the time of RHT diagnosis and from the use of the MDRD study formula to calculate eGFR. Using this formula results in lower eGFR values in women than in men. Additionally, the higher prevalence of renal dysfunction in patients with RHT compared to those without RHT may be due to higher PP values. PP was higher in women with RHT in comparison with men with RHT, which is associated with a detrimental effect on renal vasculature.

It is highlighted in the current guidelines that patients with $\mathrm{HT}$ need to be classified not only regarding the severity of HT but also based on CV risk evaluation [1]. 

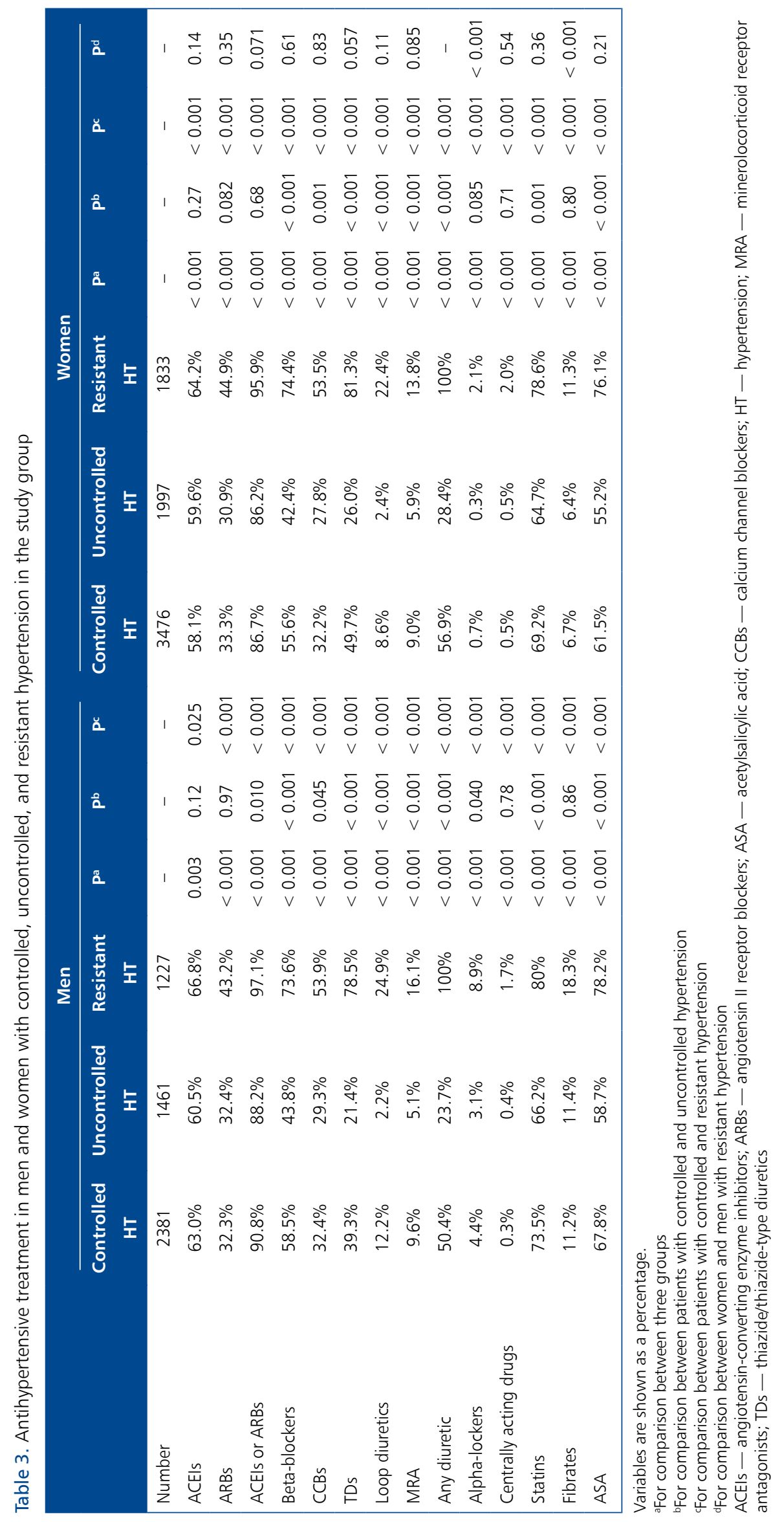


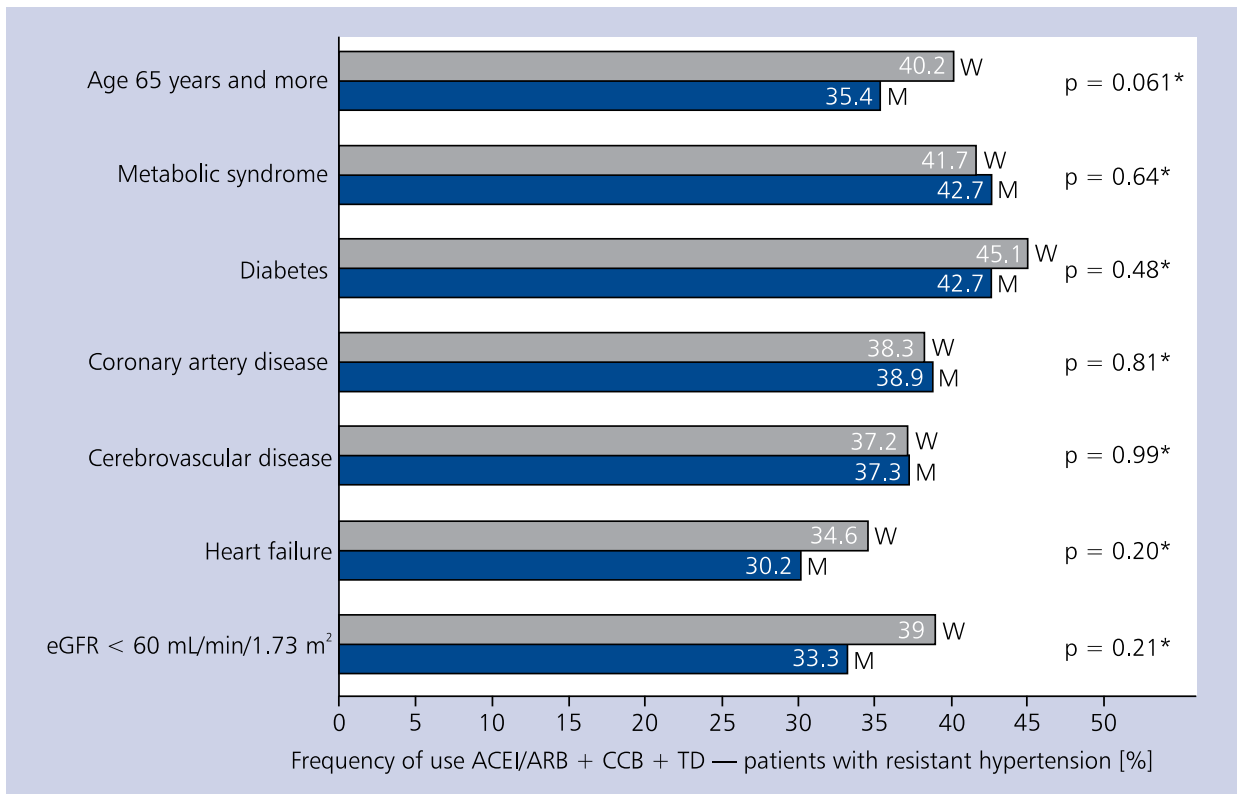

Figure 3. The frequency of using the preferred three-drug combinations in relation to coexisting clinical conditions in patients with resistant hypertension, $\mathrm{P}$ value for comparison between patients with or without coexisting clinical condition; ACE — angiotensin converting enzyme; ARB - angiotensin receptor blocker; CCB - calcium channel blocker; eGFR - estimated glomerular filtration rate; TD - thiazide/thiazide-type diuretic; $\mathrm{W}$ - women; $\mathrm{M}$ - men; ${ }^{*} \mathrm{p}$ value for the patients with or without coexisting clinical condition

Table 4. Multivariate model assessing an independent association of factors with the presence of resistant hypertension

\begin{tabular}{|c|c|c|c|c|c|c|}
\hline \multirow{2}{*}{$\begin{array}{l}\text { Factors related with } \\
\text { resistant hypertension }\end{array}$} & \multicolumn{3}{|c|}{ Male } & \multicolumn{3}{|c|}{ Female } \\
\hline & OR & $95 \% \mathrm{Cl}$ & $\mathbf{P}$ & OR & $95 \% \mathrm{Cl}$ & $\mathbf{P}$ \\
\hline Pulse pressure ${ }^{a}$ & 1.66 & $1.55-1.79$ & $<0.001$ & 1.86 & $1.75-1.98$ & $<0.001$ \\
\hline Abdominal obesity & - & - & - & 1.24 & $1.02-1.51$ & 0.035 \\
\hline Metabolic syndrome & 1.86 & $1.55-2.22$ & $<0.001$ & 1.44 & $1.18-1.77$ & $<0.001$ \\
\hline Diabetes & - & - & - & - & - & - \\
\hline Coronary artery disease & 1.41 & $1.18-1.67$ & $<0.001$ & 1.80 & $1.55-2.10$ & $<0.001$ \\
\hline Cerebrovascular disease & - & - & - & 1.25 & $1.01-1.55$ & 0.039 \\
\hline Treatment with NSAIDs & 1.48 & $1.20-1.82$ & $<0.001$ & - & - & - \\
\hline Diseases causing disability ${ }^{b}$ & - & - & - & 1.34 & $1.09-1.64$ & 0.005 \\
\hline Depression/anxiety & - & - & - & - & - & - \\
\hline $\mathrm{eGFR}<60 \mathrm{~mL} / \mathrm{min} / 1.73 \mathrm{~m}^{2}$ & 1.37 & $1.06-1.77$ & 0.015 & 1.23 & $1.06-1.43$ & 0.008 \\
\hline
\end{tabular}

${ }^{a}$ For $10-\mathrm{mm} \mathrm{Hg}$ increase; ${ }^{\circ}$ For 10-year increase; $\mathrm{Cl}$ - confidence interval; eGFR — estimated glomerular filtration rate; NSAIDs — nonsteroidal anti-inflammatory drugs; OR — odds ratio

In our study, the assessment of the $\mathrm{CV}$ risk according to the 2013 ESH/ESC guidelines showed that women with RHT more frequently had high and very high CV risk than men with RHT.

Comparing to the WOBASZ and WOBASZ-Senior study conducted in Polish population at the age of 20-74 and $<75$ years, our results are similar mostly due to the higher frequency of abdominal obesity in women in comparison with men $[8,18]$.
It was also shown in our study that depression and diseases causing disability were more frequent in women than in men with RHT.

Our results also indicate that, in general, there were no significant differences between the preferred drug combination schemes. Both ACEI and ARB were used in most of the patients with RHT equally in men and women, followed by thiazide/thiazide-type diuretics, beta-blockers, and CCB. 
The evaluation of the preferred drug combination based on the $2013 \mathrm{ESH} / \mathrm{ESC}$ guidelines showed that a regimen consisting of ACEI or ARB, CCB, and thiazide/thiazide-type was used in less than half of the patients with RHT, but more often in those with coexisting MS or diabetes [2].

In our study, the rate of alpha-blockers intake was higher in men in comparison to women with RHT, which might be because alpha-blockers are more frequently prescribed in the male population with benign prostatic hyperplasia.

Although in the presented study there was only one significant difference in the drug intake between the genders, it should be noticed that there are reports indicating some differences in pharmacokinetics, pharmacodynamics, and adverse drug reactions between men and women [19].

A major strength of our study is that we analysed RHT in a large cohort of patients in Poland characterised by clinical features and cluster of $\mathrm{CV}$ risk factors.

\section{Limitations of the study}

Our study has certain limitations. First, the adherence to antihypertensive treatment could not be assessed or controlled. Our estimation was based on the physician's judgement of the patient's adherence to treatment. The lower rate of patients with LDL-cholesterol levels below the treatment goal among patients with RHT might suggest their nonadherence to a recommended treatment. Moreover, we based our analysis on clinical BP measurements, and BP monitoring was not used to exclude those with white coat HT. Another limitation, typical for observational studies, is the lack of forced titrated treatment. Therefore, among patients with uncontrolled HT treated with two or even three drugs (without diuretic), there is a potential subgroup of patients with RHT. Yet another limitation was the cross-sectional design of the study, which did not allow us to examine the effect of RHT on the development and progression of complications. The prevalence of RHT could have been overestimated in both men and women because the participants were not checked for secondary forms of HT; therefore, we cannot exclude the possibility that some patients with secondary HT were misclassified as having RHT.

Additionally, most of the participating patients underwent a laboratory examination, and a substantial percentage did not undergo a carotid ultrasound or microalbuminuria estimation before the evaluation. The lack of this information about vascular and renal target organ damage may have led to an underestimation of $\mathrm{CV}$ risk in these patients.

\section{CONCLUSIONS}

In conclusion, our study based on a large group of treated hypertensive men and women showed that RHT is relatively common in both genders, with the frequency being comparable in both groups. However, with the exception of MS and renal function, no other major differences in clinical characteristics, associated factors, and HT treatment were found between both groups.

Moreover, women with RHT in comparison to men are characterised more often by a high and very high $\mathrm{CV}$ risk and therefore should require appropriate intensive drug therapy interventions. The underuse of preferred antihypertensive drug combinations may contribute to uncontrolled BP levels both in women and men.

\section{Conflict of interest: none declared}

\section{References}

1. Tykarski A, Narkiewicz K, Gaciong Z, et al. 2015 guidelines for the management of hypertension. Recommendations of the Polish Society of Hypertension - short version. Kardiol Pol. 2015; 73(8): 676-700, doi: 10.5603/KP.2015.0157, indexed in Pubmed: 26304155

2. Regitz-Zagrosek V, Oertelt-Prigione S, Prescott E, et al. Gender in cardiovascular diseases: impact on clinical manifestations, management, and outcomes. Eur Heart J. 2016; 37(1): 24-34, doi: 10.1093/eurheartj/ehv598, indexed in Pubmed: 26530104.

3. Gupta AK, Nasothimiou EG, Chang CL, et al. Baseline predictors of resistant hypertension in the Anglo-Scandinavian Cardiac Outcome Trial (ASCOT): a risk score to identify those at high-risk. J Hypertens. 2011; 29(10): 2004-2013, doi: 10.1097/HJH.0b013e32834a8a42, indexed in Pubmed: 21881528 .

4. Zdrojewski T. Rozpowszechnienie i kontrola nadciśnienia tętniczego w Polsce - porównanie z wybranymi krajami w Europie i na świecie. W: Więcek A, Januszewicz A, Szczepańska-Sadowska E (red.) Hipertensjologia. Patogeneza, diagnostyka i leczenia nadciśnienia tętniczego. Medycyna Praktyczna, Kraków, 1-5.

5. Solini A, Zoppini G, Orsi E, et al. Resistant hypertension in patients with type 2 diabetes: clinical correlates and association with complications. J Hypertens. 2014; 32(12): 2401-2410; discussion 2410, doi: 10.1097/HJH.0000000000000350, indexed in Pubmed: 25198422.

6. Boswell L, Pascual J, Oliveras A. Resistant hypertension: do all definitions describe the same patients? J Hum Hypertens. 2015; 29(9): 530-534, doi: 10.1038/jhh.2014.128, indexed in Pubmed: 25589214.

7. Prejbisz A, Klocek M, Gąsowski J, et al. Factors associated with resistant hypertension in a large cohort of hypertensive patients: the Pol-Fokus study. Pol Arch Med Wewn. 2015; 125(4): 249-259, indexed in Pubmed: 25764004.

8. Piotrowicz K, Prejbisz A, Klocek M, et al. Subclinical mood and cognition impairments and blood pressure control in a large cohort of elderly hypertensives. J Am Med Dir Assoc. 2016; 17(9): 864.e17-864.e22, doi: 10.1016/j.jamda.2016.06.021, indexed in Pubmed: 27502451.

9. Egan BM, Zhao Y, Li J, et al. Prevalence of optimal treatment regimens in patients with apparent treatment-resistant hypertension based on office blood pressure in a community-based practice network. Hypertension. 2013; 62(4): 691-697, doi: 10.1161/ /HYPERTENSIONAHA.113.01448, indexed in Pubmed: 23918752

10. Muntner P, Davis BR, Cushman WC, et al. Treatment-resistant hypertension and the incidence of cardiovascular disease and end-stage renal disease: results from the Antihypertensive and Lipid-Lowering Treatment to Prevent Heart Attack Trial (ALLHAT). Hypertension. 2014; 64(5): 1012-1021, doi: 10.1161/HYPERTENSIONAHA.114.03850, indexed in Pubmed: 25259745.

11. Calhoun DA, Booth JN, Oparil S, et al. Refractory hypertension: determination of prevalence, risk factors, and comorbidities in 
a large, population-based cohort. Hypertension. 2014; 63(3): 451-458, doi: 10.1161/HYPERTENSIONAHA.113.02026, indexed in Pubmed: 24324035.

12. Smith SM, Gong Y, Handberg E, et al. Predictors and outcomes of resistant hypertension among patients with coronary artery disease and hypertension. J Hypertens. 2014; 32(3): 635-643, doi: 10.1097/HJH.0000000000000051, indexed in Pubmed: 24299915.

13. Achelrod D, Wenzel U, Frey S. Systematic review and meta-analysis of the prevalence of resistant hypertension in treated hypertensive populations. Am J Hypertens. 2015; 28(3): 355-361, doi: 10.1093/ajh/hpu151, indexed in Pubmed: 25156625.

14. Chia YC, Ching SM. Prevalence and predictors of resistant hypertension in a primary care setting: a cross-sectional study. BMC Fam Pract. 2014; 15: 131, doi: 10.1186/1471-2296-15-131, indexed in Pubmed: 24997591.

15. Brambilla G, Bombelli M, Seravalle G, et al. Prevalence and clinical characteristics of patients with true resistant hypertension in central and Eastern Europe: data from the BP-CARE study. J Hypertens. 2013; 31(10): 2018-2024, doi: 10.1097/HJH.0b013e328363823f, indexed in Pubmed: 23838657

16. Egan BM, Zhao Y, Axon RN, et al. Uncontrolled and apparent treatment resistant hypertension in the United States, 1988 to 2008. Circulation. 2011; 124(9): 1046-1058, doi: 10.1161/CIRCULATIONAHA.111.030189, indexed in Pubmed: 21824920.

17. Banegas JR, Ruilope LM, de la Sierra A, et al. High prevalence of masked uncontrolled hypertension in people with treated hypertension. Eur Heart J. 2014; 35(46): 3304-3312, doi: 10.1093/eurhearti/ehu016, indexed in Pubmed: 24497346.

18. Czarnecka D, Kawecka-Jaszcz K, Klocek M. Nadciśnienie tętnicze u kobiet. W: Choroby Serca u Kobiet. Wyd. II. In: Kornacewicz-Jach Z, Janion M (red.). 2015.

19. Rosano GMC, Lewis B, Agewall S, et al. Gender differences in the effect of cardiovascular drugs: a position document of the Working Group on Pharmacology and Drug Therapy of the ESC. Eur Heart J. 2015; 36(40): 2677-2680, doi: 10.1093/eurheartj/ehv161, indexed in Pubmed: 25948737.

\title{
Związek między płcią, charakterystyką kliniczną, czynnikami towarzyszącymi i leczeniem pacjentów z opornym nadciśnieniem tętniczym
}

\author{
Katarzyna M. Hanus ${ }^{1}$, Aleksander Prejbisz' ${ }^{1}$, Jerzy Gąsowski², Marek Klocek³ ${ }^{3}$ Roman Topór-Mądry, 5 , \\ Wiktoria Leśniak ${ }^{6}$, Marek Kabat ${ }^{1}$, Danuta Czarnecka ${ }^{3}$, Kalina Kawecka-Jaszcz ${ }^{3}$, \\ Krzysztof Narkiewicz ${ }^{7}$, Andrzej Januszewicz ${ }^{1}$ \\ ${ }^{1}$ Klinika Nadciśnienia Tętniczego, Instytut Kardiologii, Warszawa-Anin \\ ${ }^{2}$ Katedra Chorób Wewnętrznych i Gerontologii, Uniwersytet Jagielloński, Collegium Medicum, Kraków \\ 3| Klinika Kardiologii i Elektrokardiologii Interwencyjnej oraz Nadciśnienia Tętniczego, Uniwersytet Jagielloński, Collegium Medicum, Kraków \\ ${ }^{4}$ Zakład Epidemiologii i Badań Populacyjnych, Instytut Zdrowia Publicznego, Uniwersytet Jagielloński, Collegium Medicum, Kraków \\ ${ }^{5}$ Wydział Nauk o Zdrowiu, Uniwersytet Medyczny we Wrocławiu, Wrocław \\ ${ }^{\prime}$ Z Zakład Chorób Wewnętrznych, Uniwersytet Jagielloński, Collegium Medicum, Kraków \\ `Zakład Nadciśnienia Tętniczego, Katedra Nadciśnienia Tętniczego i Diabetologii, Gdański Uniwersytet Medyczny, Gdańsk
}

\section{Streszczen ie}

Wstęp i cel: Opublikowane dotychczas wyniki badań dotyczących różnic w częstości występowania opornego nadciśnienia tętniczego (RHT) u kobiet i mężczyzn są sprzeczne. Istnieje ograniczona liczba danych dotyczących różnic między kobietami i mężczyznami z RHT w odniesieniu do charakterystyki klinicznej, stanów oraz chorób współistniejących, a także sposobu leczenia nadciśnienia tętniczego (HT). 
Metody: Do przekrojowego badania, opartego na ocenie ankietowej, włączono 7306 kobiet i 5069 mężczyzn chorych na HT, zgłaszających się na rutynową wizytę u lekarza rodzinnego lub u lekarza specjalisty. Lekarze uczestniczący w badaniu zostali dobrani tak, aby zapewnić reprezentatywną grupę pacjentów z każdego województwa. Kryteria włączenia obejmowały wiek $\geq 18$ lat i co najmniej roczny wywiad farmakologicznego leczenia HT. Pomiar ciśnienia tętniczego wykonano 2-krotnie w pozycji siedzącej zgodnie z zasadami przyjętymi w wytycznych European Society of Hypertension/European Society of Cardiology (ESH/ESC); obliczono średnią wartość z dwóch pomiarów. Prawidłowa kontrola HT została zdefiniowana jako wartości ciśnienia $<140 \mathrm{~mm} \mathrm{Hg} \mathrm{i}<90 \mathrm{~mm} \mathrm{Hg}$. Pacjenci zostali podzieleni na trzy grupy: nadciśnienie tętnicze kontrolowane, niekontrolowane (niespełniające kryteriów RHT) oraz oporne nadciśnienie tętnicze (niekontrolowane nadciśnienie mimo stosowania minimum 3 leków hipotensyjnych, w tym diuretyku). Ryzyko sercowo-naczyniowe zostało ocenione wg wytycznych ESH/ESC z 2013 roku.

Wyniki: Nie stwierdzono istotnych różnic w stopniu kontroli HT: kontrolowane (47,6\% vs. 47,9\%), niekontrolowane (27,3\% vs. $28,8 \%$ ) oraz oporne (25,1\% vs. $24,4 \%)$ między kobietami i mężczyznami ( $p=0,17)$. RHT występowało rzadziej u kobiet niż u mężczyzn poniżej 40. rż. (9,4\% vs. 19,4\%; $p=0,083)$ oraz pomiędzy 40. a 65. rż. (20,4\% vs. 23,3\%; $p=0,019)$, natomiast wśród chorych powyżej 65 lat RHT częściej obserwowano u kobiet (28,1\% vs. 26,4\%; $p=0,089)$. U chorych z RHT nie stwierdzono różnic między kobietami i mężczyznami w wartościach skurczowego ciśnienia tętniczego. Kobiety z RHT charakteryzowały się niższymi wartościami rozkurczowego ciśnienia tętniczego i wyższymi wartościami ciśnienia tętna w porównaniu z mężczyznami. W grupie chorych z RHT kobiety, w porównaniu z mężczyznami, cechowały się starszym wiekiem i niższą wartością oszacowanego wskaźnika filtracji kłębuszkowej (eGFR). Przebyty udar/przejściowy atak niedokrwienny mózgu (TIA; 16,9\% vs. 14,3\%; p =0,034), otyłość brzuszna i zespół metaboliczny (MS; 70,5\% vs. 60,1\%; p < 0,001) były częstsze wśród kobiet niż mężczyzn z RHT. Ryzyko sercowo-naczyniowe wysokie i bardzo wysokie było znacząco częstsze wśród kobiet z RHT w porównaniu z mężczyznami z RHT (70,9\% vs. 67,3\%; p < 0,001). Mężczyźni z RHT częściej otrzymywali antagonistów aldosteronu (16,1\% vs. 13,8\%) oraz alfa-adrenolityki (8,9\% vs. 2,1\%; $p<0,001)$, rzadziej zaś diuretyki tiazydowe/tiazydopodobne (78,5\% vs. 81,3\%; $\mathrm{p}=0,032)$. W analizie wieloczynnikowej parametrami związanymi z obecnością RHT były, zarówno u kobiet, jak i u mężczyzn: wyższe ciśnienie tętna, MS, choroba wieńcowa i eGFR $<60 \mathrm{ml} / \mathrm{min} / 1,73$ m². Wśród kobiet RHT było również dodatkowo istotnie związane z otyłością brzuszną, przebytym udarem/TIA oraz obecnością chorób związanych z niepełnosprawnością. Z kolei u mężczyzn RHT dodatkowo wiązało się z chorobami wymagającymi stosowania niesteroidowych leków przeciwzapalnych.

Wnioski: Pomimo braku różnic w częstości występowania RHT między kobietami i mężczyznami wyodrębniono różnice w odniesieniu do profilu czynników ryzyka sercowo-naczyniowego i stanów związanych z RHT.

Słowa kluczowe: leczenie hipotensyjne, ryzyko sercowo-naczyniowe, oporne nadciśnienie tętnicze

Kardiol Pol 2017; 75, 5: 421-431 